\title{
Comparative Analysis of Economic Efficiency of Irrigated and Rain-Fed Vegetable production in Kersa District of East Hararghe Zone, Oromia, Ethiopia
}

\author{
Kibret Ketema \\ Oromia Agricultural Research Institute, Fadis Agricultural Research Centre, \\ P.O. Box 904, Harar, Ethiopia
}

\begin{abstract}
The aim of the study was to compare economic efficiency of vegetable production and identify factors determining efficiencies level of vegetable producers under irrigated and rain-fed conditions in Kersa district of East Hararghe Zone, Oromia, Ethiopia. The cross-sectional data and collected from160farm households (80 irrigation users and 80 irrigation non-users) randomly selected. The Stochastic and Tobit models were used to estimate efficiency levels for both farm groups in the study area. The results of the stochastic frontier model indicate that the mean technical (TE), allocative (AE) and economic efficiency(EE) of irrigation users were 90\%, 64\% and 58\%, respectively whereas the mean technical (TE), allocative (AE) and economic efficiency(EE)of irrigation non-user farm households were $74 \%, 54 \%$ and $40 \%$, respectively. This indicates that irrigation users and irrigation nonusers could increase their vegetable production by $10 \%$ and $26 \%$, respectively. Alternatively, they can reduce, on average, their cost of production by $36 \%$ and $46 \%$ for irrigation users and irrigation non-users, respectively. The results of the Tobit model revealed that education level, cooperative membership, farming experience, extension contact and soil fertility status were significantly determined resource use efficiencies of irrigation users and nonusers, respectively. Family size positively and significantly affects efficiency of irrigation users, but negatively related with the efficiency of irrigation non-user farm households. The findings show that irrigation users are relatively efficient as compared to irrigation non users, and a high degree of inefficiency for irrigation non users has been reported. Hence, it has been argued that improve efficiency and productivity of the households requires eliminating inefficiency, particular, for irrigation non users by supplementing the rain-fed vegetable production through providing satisfactory institutional support such as rain-water harvesting and soil-water conservation techniques, expansion of irrigation and improved techniques of irrigation should be strengthened and empowered. Moreover, cooperatives and extension services should be strengthened to reduce the knowledge gap in resource allocation for vegetable production.
\end{abstract}

Keywords: Vegetables, Irrigation, Rainfed, Economic Efficiency, Stochastic Frontier, Tobit

DOI: $10.7176 / \mathrm{JESD} / 12-5-04$

Publication date:March $31^{\text {st }} 2021$

\section{Introduction}

Agriculture is the mainstay of Ethiopian economy contributing about $40 \%$ of the GDP, $72.7 \%$ of employment and $81 \%$ of the export (UNDP, 2015). Vegetable crops play a significant role in Ethiopia, both in income and social spheres for improving income and nutrition status. Further, it provides employment opportunities as their management being labour intensive. However, Ethiopian agriculture is dominated by rain-fed agriculture, where the performance of the sector is highly dependent amount and distribution of rainfall that makes the sector highly vulnerable to drought and other natural calamities. The use of improved technologies such as chemical fertilizer, improved seed, irrigation, is very low in Ethiopia (CSA, 2018).

Vegetables are sources of vitamins, minerals and income for those involved in production and marketing. Its production gives an opportunity for intensive production and increases male and female farmer's participation in the market (Emana and Gebremedihin, 2007). Ethiopia has favorable weather conditions for the production of a number of vegetable crops by small-scale as well as by commercial farmers in different parts of the country. In addition, the abundant labor, land and water resources give an opportunity for the production of vegetables both under rain-fed and irrigated conditions (Fekadu \& Dandena, 2006). In Ethiopia, the area under vegetable crops was estimated to be 442,276.04 hectares with a total production of 53,001,366.96 quintals in the year of 2017/18. Moreover, Oromia region has diverse agro-ecology that is suitable for growing vegetable crops, and the area under vegetable crops was estimated to be $176,402.17$ hectares with a total production of $21,348,216.86$ quintals in the year of 2017/18 (CSA, 2018).

East Hararghe Zone, proximity to market and availability irrigation water, encourage farmers to grow different vegetable crops both under rain-fed and irrigated condition, and in 2016/17 production year 220,903.00 smallholder farmers were engaged in vegetable production, and 3,475,486.07 vegetables were produced in East Hararghe Zone (CSA, 2016). Vegetable production has significant contribution in supporting household income and used as source of food in zone. In the Kersa district, different vegetables are grown with different intensities 
depending on environmental condition and level of marketability. Therefore, this study was aimed to compare economic efficiency of irrigation user and non-user vegetable grower farm households.

\section{Methodology}

\subsection{Data and sample selection}

Both primary and secondary data were collected and used to determine production efficiency and factors that affect efficiency of irrigated and rain-fed vegetable production. Data related to household characteristics, input and output were collected using structured interview schedule. A multi-stage sampling technique was employed to analyze economic efficiency of small holder vegetable producers. Multi stage sampling procedure was employed to select Kebeles and sample households. Firstly, Kersa district was purposively selected due to its potential in irrigation water availability and vegetable production. Out of 12 Kebeles which are major vegetable producers under irrigation and rain-fed, 6 Kebeles were selected randomly. In the second stage, 160 farm households consisting of 80 irrigation users and 80 non-users were selected using random sampling technique taking into account probability proportional to size of the households.

\subsection{Method of data analysis}

\section{Specification of the econometric models}

Stochastic frontier analysis was introduced by the pioneering work of Aigner et al. (1977) and Meeusen and Van Broeck (1977). The method recognizes component error term (random deviation and inefficiency) as major source of deviation from the production frontier. Hence, the stochastic frontier production function for this study is specified as follows:

$$
\ln Y_{i j}=f\left(x_{i j}, \beta\right)+\varepsilon_{i j}
$$

Where $\ln$ denotes the natural logarithm, $\mathrm{i}$ is the $\mathrm{i}^{\text {th }}$ farm in the sample in the $\mathrm{j}^{\text {th }}$ farm groups, $\mathrm{Y}_{\mathrm{ij}}$ denotes the value of vegetable output for $\mathrm{i}^{\text {th }}$ farm in $\mathrm{j}^{\text {th }}$ group, $X_{i j}$ is the quantity of inputs used in the vegetable production by $\mathrm{i}^{\text {th }}$ farm in the $\mathrm{j}^{\text {th }}$ group, $\beta$-is parameters to be estimated, $f($.$) denotes an appropriate functional form, \varepsilon_{i j}$-which is defined as $\varepsilon_{i j}=v_{i j}-u_{i j}, v_{i j}$-is the symmetric error component that accounts for random shocks, while $u_{i j}$, is a one sided error component that accounting for inefficiency effect. Furthermore, Battese and Corra (1977) the log likelihood function of the model is specified as:

$$
\begin{aligned}
& \ln L=\frac{N}{2} \ln \left(\frac{\pi}{2}\right)-\frac{N}{2} \ln \delta^{2}+\sum_{i=1}^{N} \ln \left[1-F\left(Z_{i j}\right)\right]-\frac{1}{2 \delta^{2}} \sum_{i}^{N} \varepsilon_{i j}^{2} \\
& \text { Where, } Z_{i j}=\frac{\varepsilon_{i j}}{\delta^{2}} \sqrt{\frac{\gamma}{1-\gamma}}, \sigma^{2}=\sigma_{v}^{2}+\sigma_{u}^{2} \text { and } \gamma=\delta_{u}^{2} / \delta^{2} \text { are variance parameters, }
\end{aligned}
$$

$\varepsilon_{i j}=\ln \mathrm{Y}_{i j}-\mathrm{X}_{i j} \beta$ is the residual of the model, $\mathrm{N}$ is number of observations and $\mathrm{F}($.$) is the standard normal$ distribution. The parameter $\gamma$ is used to test whether the technical efficiency affects vegetable output value or not.

Similarly, the significance of $\delta^{2}$ indicate whether the conventional average production function adequately represent the data or not. The parameters, $\beta, \sigma^{2}, \gamma^{2}$ of the stochastic production function specified in equation (4) was estimated using maximum likelihood (ML), which is consistent and asymptotically efficient (Coelli et al., 1998).

The production function could be estimated through an alternative form, called dual, such as cost or profit function. According to Arega and Rashid (2005), inadequate farm level price data together with little or no input price variation across farms in Ethiopia precludes any econometric estimation of a cost function through application of Cobb-Douglas production function. Even though Cobb Douglas model assumes unitary elasticity of substitution, constant production elasticity and constant factor demand; if the interest is to analyses the efficiency, it will have adequate representation of the technology and insignificant impact on measurement of efficiency (Coelli et al., 1998). When farmers operate small farms, the technology is unlikely to be substantially affected by variable returns to scale (Coelli, 1995). Given the assumption of Cobb-Douglas production function is self-dual (Xu, X., and Jeffrey, 1998). Thus, the dual cost frontier of the production function in equation (3) is given by:

$$
\ln C_{i j}=\alpha_{0}+\sum_{K=1}^{K} \alpha_{i j k} \ln P_{i j k}+\alpha_{8} \ln Y_{i j}^{*}+v_{i j}+v_{i j}
$$


Where $i$ refers to the $i^{\text {th }}$ sample farm; $j$ is number of farm groups; $\mathrm{k}$ is number of inputs; $C_{i j}$ is the minimum cost of production, $P_{i j}$ is a vector of $i^{\text {th }}$ input prices, $O S$ are vector of parameters to be estimated and $Y_{i j}^{*}$ is vegetable output value adjusted for noise $\left(v_{\mathrm{ij}}\right)$.

Following the Bravo and Pinheiro (1997), adjusted output value $\left(Y_{i j}^{*}\right)$ is estimated by:

$$
Y_{i j}^{*}=f\left(X_{i j}, \beta_{i j}\right)-u_{i j}=Y_{i j}-v_{i j}
$$

Sharma et al. (1999) suggested that assuming the self-dual Cobb Douglas production function, the dual cost frontier is derived algebraically and can be written in the following form:

$$
C_{i j}=f\left(P_{i j}, Y_{i j}{ }^{*}, \alpha_{i j}\right)
$$

Where $\mathrm{C}_{\mathrm{ij}}, Y_{i j}^{*}, \mathrm{P}_{\mathrm{ij}}$ and $\alpha_{i j}$ are described above.

The economically efficient input vector for $i^{\text {th }}$ farm, $X_{i j e}$, is derived by applying Shephard's Lemma ( Shephard, 1970 cited in Jema, 2008; Nyagaka et al., 2011) and substituting the farm's input price and adjusted output level into the derived system of input demand equations given:

$$
\partial C_{i j} / \partial P_{i j}=X_{i e}\left(P_{i j}, Y_{i j}^{*}, \alpha_{i j}\right)
$$

Where, $C_{i j}, Y_{i j}^{*}$, and $\alpha_{i j}$ are as described above.

The observed, technically and economically efficient costs of production of the $i^{\text {th }}$ farm are then equal to $\sum X_{i j} P_{i j}, \sum X_{i j t} P_{i j}$ and $\sum X_{i j e} P_{i j}$; respectiveslly. According to Sharma et al. (1999), these cost measures are used to estimate the technical, allocative and economic efficiencies index for $i^{\text {th }}$ farm in the $\mathrm{j}^{\text {th }}$ group, respectivelly. Hence, the $\mathrm{i}^{\text {th }}$ farm in the $\mathrm{j}^{\text {th }}$ group of technical (TE), allocative (AE) and economic efficiency (EE) was obtained as follows:

$$
\begin{aligned}
T E_{i j} & =\sum X_{i j t} P_{i j} / \sum X_{i j} P_{i j} \\
E E_{i j} & =\sum X_{i j e} P_{i j} / \sum X_{i j} P_{i j}
\end{aligned}
$$

Following Farrell (1957), the AE index can be derived from Equations (10 and (11) as follows:

$$
A E=E E / T E=\sum X_{i j e} P_{i j} / \sum X_{i j t} P_{i j}
$$

The Cobb-Douglas stochastic production function that specified in equation (4) was specified as:

$$
\begin{aligned}
\ln Y_{i j}= & \beta_{0}+\beta_{1} \ln \left(A_{i j}\right)+\beta_{2} \ln \left(L_{i j}\right)+\beta_{3} \ln \left(F_{i j}\right)+\beta_{4} \ln \left(S_{i j}\right)+\beta_{5} \ln \left(O X_{i j}\right)+\beta_{6} \ln \left(P_{i j}\right)+\beta_{7} \ln \left(O F_{i j}\right) \\
& +\beta_{8} \ln \left(I_{i j}\right)+v_{i j}-u_{i j}
\end{aligned}
$$

Where,

$\mathrm{i}$-is the number of sample households in the $\mathrm{j}^{\text {th }}$ groups $(\mathrm{j}=1,2)$,

$\mathrm{Y}_{\mathrm{ij}}$-represents the vegetable output value (in Birr) for $\mathrm{i}^{\text {th }}$ households in the $\mathrm{j}^{\text {th }}$ group of farms,

$A_{i j}-I_{i j}$ is the explanatory variables by the $i^{\text {th }}$ farmer in $j^{\text {th }}$ group,

$V_{i j}$-is random variation in output value due to factors outside the control of farmers,

$u_{i j}$-non-negative random variable which captures the inefficiency effects of $i^{\text {th }}$ household in the $\mathrm{j}^{\text {th }}$ group of farms in the study area.

Thus, in this estimation procedure, once the efficiency score obtained the determinants of efficiency estimated in the second stage, the efficiency score was regressed against farm specific factors using Tobit model. Previous studies widely used Tobit model to analyze the effect of farm specific factors on efficiency level of farm households by Jema (2008), Bamlaku et al. (2009) and Mussa et al. (2011). Therefore, to assess the effect of, socio-economic and institutional factors on farmers' resource use efficiency, Two Limit Tobit model was used as the efficiencies scores lie within the range of 0 and 1 . At the distribution of the estimated efficiencies is censored from above at the value 1. Then, following Gujarati (2004) the Tobit model was estimated as follows:

$$
\begin{aligned}
& E_{i j}^{*}=\delta_{0}+\delta_{i j} Z_{i j}+v \\
& E_{i j}=\max \left(0, E^{*}\right)
\end{aligned}
$$




$$
E_{i j}=1 \text { if } E_{i j}^{*} \geq 1, E_{i j}=E_{i j}^{*} \text { if } E^{*}<1
$$

Where, $E_{\mathrm{ij}}$ is an efficiency score (TE, AE and EE) of the $\mathrm{i}^{\text {th }}$ household in $\mathrm{j}^{\text {th }}$ group of farms, $\delta_{0}$ and $\delta_{\mathrm{ij}}$ is parameters to be estimated; $Z_{\mathrm{ij}}$ is socio-economic and institutional variables that affect farm households'efficiency and $V$ is a random error term, assumed to be $\mathrm{N}\left(0, \delta^{2}\right)$ and $E S_{i j}^{*}$ is the latent variable.

\section{Results and Discussion}

\subsection{Econometric Model Results}

The multi-collinearity test using Variance Inflation Factor (VIF) showed the absence of a severe multi-collinearity in each and in all cases, it was found to be the value of VIF less than 10. This indicates that there were no serious multi-collinearity problems among the explanatory variables that entered into the frontier and Tobit model. Table 1 showed the specification tests were conducted to assess various assumptions related to the model specification and to check the fitness of the model.

Table 1. Summary of the test of hypothesis about assumption stochastic frontier model

\begin{tabular}{llllll}
\hline Null hypothesis & \multicolumn{2}{l}{ Irrigation users $(\mathrm{n}=80)$} & \multicolumn{2}{l}{ Irrigation non-users $(\mathrm{n}=80)$} \\
\cline { 2 - 6 } & LR-value & $\begin{array}{l}\text { Critical value } \\
\left(\chi^{2}\right)\end{array}$ & LR-value & $\begin{array}{l}\text { Critical } \\
\left(\chi^{2}\right)\end{array}$ & value \\
\hline $\mathrm{H}_{0}: \mu_{\mathrm{ij}}=0$ & 1.59 & $3.84^{* *}$ & 2.21 & $3.84^{* *}$ \\
$\mathrm{H}_{0}: \gamma_{\mathrm{ij}}=0$ & 23.41 & $3.84^{* *}$ & 26.35 & $3.84^{* *}$ \\
$\mathrm{H}_{0}: \delta_{1}=\ldots=\delta_{14} / \delta_{15}=0$ & 51.85 & $24.99^{* *}$ & 68.73 & $23.68^{* *}$ \\
\hline
\end{tabular}

Source: Own computation, 2017

\subsection{Estimation of production and cost functions}

Maximum Likelihood (ML) parameter estimates of the stochastic frontier Cobb-Douglas production function for both farm groups are summarized and presented in Table 2. The estimate for the variance parameters, $\sigma^{2}$ is 0.126 for irrigation users and 0.335 for irrigation non-users sample households is significantly different from zero at $1 \%$ for both farm groups. This indicates statistical confirmation of our presumption that there are differences in efficiency and the correctness of the specified distributional assumption of the composite error term.

Table 2. ML estimated Cobb-Douglas stochastic frontier production function

\begin{tabular}{llccc}
\hline Variables & \multicolumn{2}{l}{ Irrigation-user $(\mathrm{n}=80)$} & \multicolumn{2}{c}{ Irrigation-non user $(\mathrm{n}=80)$} \\
\cline { 2 - 5 } & Coefficients & Std. error & Coefficients & Std. error \\
\hline Constant & $3.038^{* * *}$ & 0.231 & $2.377^{* * *}$ & 0.131 \\
Land (hectare) & $0.231^{* *}$ & 0.051 & $0.133^{* *}$ & 0.042 \\
Labour (MD/hectare) & $0.249^{* * *}$ & 0.042 & $0.256^{* * *}$ & 0.035 \\
Oxen-pair day & 0.019 & 0.028 & $0.152^{* *}$ & 0.079 \\
Fertilizer (kg/hectare) & $0.127^{* *}$ & 0.034 & 0.063 & 0.541 \\
Seed (Birr/hectare) & $0.365^{* * *}$ & 0.029 & $0.239^{* * *}$ & 0.018 \\
Pesticides (lt/hectare) & $0.195^{* *}$ & 0.047 & 0.125 & 0.514 \\
Irrigation (number) & $0.208^{* * *}$ & 0.023 & - & - \\
Manure (qt/hectare) & 0.047 & 0.305 & $0.137^{* *}$ & 0.104 \\
\hline Inefficiency effect model & \multicolumn{1}{c}{-} & - & - & - \\
\hline Sigma-squared $\left(\sigma^{2}\right)$ & $0.126^{* * *}$ & 0.027 & $0.335^{* * *}$ & 0.062 \\
Gamma $(\gamma)$ & $0.624^{* * *}$ & 0.076 & $0.561^{* * *}$ & 0.041 \\
Return to scale & $1.441^{* * *}$ & - & $1.205^{* *}$ & - \\
Log likelihood value & -129.76 & - & 18.09 & - \\
\hline Source: & & & & - \\
\hline
\end{tabular}

Source: model output, $2017,{ }^{*}$ significant at $10 \%$ level; $* *$ significant at $5 \%$ level; $* * *$ significant at $1 \%$ level of significance

The dual cost function which is derived analytically from the stochastic production function has been summarized in Table 3. The estimated values of gamma $(\gamma)$ are 0.714 and 0.826 for irrigation user and non-user households, respectively and significant at $1 \%$ level of probability. This implies that about 71 and $82.6 \%$ of the variation in the total production cost is due to differences in their cost efficiencies for irrigation users and nonusers, respectively. 
Table 3. ML estimated Cobb-Douglas stochastic frontier cost function

\begin{tabular}{llllc}
\hline Variables & \multicolumn{2}{l}{ Irrigation-user $(\mathrm{n}=80)$} & \multicolumn{2}{l}{ Irrigation-non user $(\mathrm{n}=80)$} \\
\cline { 2 - 5 } & Coefficients & Std. error & Coefficients & Std.error \\
\hline Constant & $5.363^{* * *}$ & 0.442 & $3.795^{* *}$ & 0.351 \\
Cost of land (Birr/hectare) & $0.203^{* * *}$ & 0.017 & $0.126^{* *}$ & 0.039 \\
Cost of labour (Birr/day) & $0.245^{* * *}$ & 0.032 & $0.179^{* *}$ & 0.054 \\
Cost of a pair of oxen (Birr/day) & 0.041 & 0.340 & $0.259^{* * *}$ & 0.061 \\
Cost of fertilizer (Birr/kg) & $0.321^{* * *}$ & 0.021 & 0.248 & 0.321 \\
Cost of seed (Birr/kg) & $0.291^{* * *}$ & 0.044 & $0.235^{* * *}$ & 0.040 \\
Cost of pesticide (Birr/lt) & $0.132^{* * *}$ & 0.023 & $0.114^{* *}$ & 0.050 \\
Cost of irrigation (Birr/hectare) & $0.015^{* *}$ & 0.011 & - & - \\
Cost of manure (Birr/qt) & $0.027^{*}$ & 0.012 & $0.012^{* *}$ & 0.007 \\
Vegetable output value (Birr/hectare) & $0.684^{* * *}$ & 0.150 & $0.427^{* *}$ & 0.133 \\
\hline Inefficiency effect model & - & - & & - \\
Sigma-squared $\left(\sigma^{2}\right)$ & $0.637^{* * *}$ & 0.037 & $1.059^{* * *}$ & 0.081 \\
Gamma $(\gamma)$ & $0.714^{* * *}$ & 0.056 & $0.826^{* * *}$ & 0.124 \\
Log likelihood value & 125.7 & - & 128.22 & - \\
\hline Source: & & - & - & - \\
\hline
\end{tabular}

Source: Model result, 2017 , *significant at $10 \%$ level; ** significant at $5 \%$ level; *** significant at $1 \%$ level of significance

\subsection{Estimation of efficiency scores}

The results of the efficiency scores indicate that there were wide ranges of variability in technical (TE), allocative (AE) and economic efficiency (EE) among vegetable producer farm households of both groups. The mean TE was estimated to be $90 \%$ with a large range of 46 to $100 \%$, and $74 \%$ with a large range of 34 to $97 \%$ for irrigation user and non-user sample households, respectively in the study area (Table 4).

The revealed that the irrigation user sample households are relatively technically efficient as compared to non-user households with $16 \%$ gap in mean TE between the two groups. The result indicates that on an average the irrigation user and non-user sample farmers tend to realize around $90 \%$ and $74 \%$ of their technical abilities, respectively. Hence, $10 \%$ and $26 \%$ of the technical potentials are not realized for irrigation users and non-users, respectively. Therefore, it is possible to improve the production level of farms by $10 \%$ for irrigation users and $26 \%$ for irrigation non-users, respectively following efficient crop management practices without increasing the level of input application. Alternatively, the irrigation users and non-user sample households, on average, can increase vegetable output value by $10 \%$ and $26 \%$, respectively given the existing level of inputs and state of technology. The result of this study further revealed that irrigation water availability might be shifts the production frontier to a higher level through reducing risk of crop failure due to moisture stress and also enhancing intensification of input use. Hence, in the study area if irrigation user farmers are realizing the $10 \%$ of the technical potentials, irrigation user farmers may be shifting their production frontier to a higher level.

The mean allocative efficiency (AE) for irrigation users and non-user households were $64 \%$ and $54 \%$ with a large range of 24 to 94 and 29 to $95 \%$, respectively with $10 \%$ gap in average allocative between the two groups in the study area, and the estimated overall average allocative efficiency was $60 \%$ (Table 4). This implies that both irrigation user and non-user farm households faced severe allocative inefficiency problems. However, irrigation user households were relatively allocatively efficient, as compared to irrigation non-user households due to the availability of irrigation water improve their decision making on the combination of inputs used with the existing market conditions. The mean $\mathrm{AE}$ of $64 \%$ and $54 \%$ indicates that if irrigation user and non-user farmers operate at full allocative efficiency levels, they can save, on average, $36 \%$ and $46 \%$ of their current cost of inputs by behaving in a cost minimizing way, respectively and gain same benefits. The study further yielded that the mean economic efficiencies (EE) of 58\% and $40 \%$ for irrigation user and non-user farm households, respectively. The $58 \%$ and $40 \%$ mean EE implies that the total cost of production of the farmers could be reduced, on the average, $42 \%$ and $60 \%$ for irrigation users and non-user farmers, respectively.

The study revealed that sample households which mainly differ in their access to irrigation facilities, had 16, 10 and $18 \%$ difference in their mean TE, AE and EE, respectively. In general, the result of this study revealed that vegetable grower farmers are less efficient with respect to $\mathrm{AE}$ and $\mathrm{EE}$ as compared to TE. This indicates that farmers are looking only for maximizing the vegetable output value without any consideration to allocate inputs in the cost minimizing manner or profit maximizing. As a result, there was low average EE score, which was attributed to both technical and allocative inefficiency of producers. However, the mean value of TE of both farm groups was higher as compared to their $\mathrm{AE}$ in the study area. However, low level of $\mathrm{AE}$ was highly contributed to low level of mean EE of vegetable grower farm households. The estimate of TE, AE and EE are consistent with the finding of (Jema, 2008; Mekombe et al., 2007) 
Table 4. Summary of estimated efficiency scores of the sample households

\begin{tabular}{llllllllll}
\hline \multirow{2}{*}{ Efficiency Scores } & \multicolumn{3}{l}{ Irrigation user $(\mathrm{n}=80)$} & \multicolumn{3}{c}{ non users $(\mathrm{n}=80)$} & \multicolumn{3}{c}{ Overall $(\mathrm{n}=160)$} \\
\cline { 2 - 11 } & TE & AE & EE & TE & AE & EE & TE & AE & EE \\
\hline Mean & 0.90 & 0.64 & 0.58 & 0.74 & 0.54 & 0.40 & 0.82 & 0.60 & 0.49 \\
Maximum & 1.00 & 0.94 & 0.94 & 0.97 & 0.95 & 0.92 & 1.00 & 0.94 & 0.94 \\
Minimum & 0.46 & 0.24 & 0.11 & 0.34 & 0.29 & 0.10 & 0.32 & 0.31 & 0.10 \\
SD & 0.12 & 0.21 & 0.17 & 0.20 & 0.19 & 0.20 & 0.17 & 0.21 & 0.20 \\
CV & 0.13 & 0.34 & 0.29 & 0.27 & 0.35 & 0.50 & 0.21 & 0.35 & 0.41 \\
\hline
\end{tabular}

Source: Model output, 2018

\subsection{Determinants of efficiency of vegetable producer farmers}

The results of tobit model showed that educational level of a farmer, and practices of technologies have positive and significant impact on economic efficiency at 5\% level for irrigation users but insignificant for non-users. This indicates that irrigation user farm level economic efficiency can be increased by providing strengthening schooling and training. Cooperative membership: as expected, the results in Table 5 indicate that membership of cooperative has a positive and statistically significant influence on economic efficiency of vegetable farmers at $5 \%$ significance level for both farm groups which suggests that farmers being membership of cooperatives tend to improve farmers' resource use efficiency as cooperatives being a source of quality inputs, information and market for their products.

Family size: from Table 10family size negatively and significantly affected the economic efficiency of vegetable farmers in the study area at 5\% significance level. This implies that farm household's with large family is inefficient as compared to households with small family in the study area. The result is agreed with findings of Jema (2008) and Jude et al. (2011). The estimated coefficient for farm size has a negative sign for economic efficiency and significant at 5\% levels of probability for irrigation non-users and positive and significant at $10 \%$ for irrigation users (Table 5). These results imply that farmers of the study area experienced with small land size this might be forced to use the existing land intensively and results smallholder farmers were more efficient as compared to farmers owened large size of land. The result agrees with findings of Jude et al. (2011) and Mussa et al. (2011).

Vegetable farming experience is positively and significantly affecting resource use efficiency of vegetable grower farmers in the study area at $5 \%$ and $10 \%$ significance level for irrigation users and non-users, respectively (Table 5). The results suggesting that the more experienced farmers are efficient in resource use, because the knowledge and skills that develop over time would help farmers to use available inputs in efficient manner. Access to irrigation: the overall sample analysis as indicated in Table 5, the estimated coefficient for access to irrigation was highly significant and positively related to economic efficiency of vegetable grower farmers in the study area. This implies that farm households who have irrigation water for their vegetable crops appeared to be more economically efficient because farmers easily manage production risk due to rainfall variability in the study area. Extension contact: the overall sample analysis indicates that the variable significantly and positively affects the efficiency of farm households at 5\% significance level in the study area (Table 5). This implies that a farmer who receives regular extension visits from extension agents appear to be more efficient. The result further shows that the advice from extension agents plays an important role in improving farmers' resource use efficiency in study area. The result is consistent with findings of (Jema, 2008; Nyagaka et al. (2011). Fertility of the land: in the same way as indicated in Table 16, the overall sample analysis shows that the effect of fertility status of land allocated to vegetable crops statistically significant and affected efficiency level positively at $1 \%$ significance level (Table 5). This implies that the fertility of land is a significant factor in determining the level of efficiency. 
Table 5. Tobit model estimated for determinants of economic efficiency

\begin{tabular}{llcc}
\hline Variables & Irrigation users $(\mathrm{n}=80)$ & Non- users $(\mathrm{n}=80)$ & Overall $(\mathrm{n}=160)$ \\
\cline { 2 - 4 } & Coefficients $(\mathrm{t})$ & Coefficients $(\mathrm{t})$ & Coefficients $(\mathrm{t})$ \\
\hline Constant & $0.555(3.09) * * *$ & $0.945(4.25) * * *$ & $0.728(4.84) * * *$ \\
Sex of household & $0.002(0.70)$ & $0.014(0.09)$ & $0.002(0.64)$ \\
Age of household & $-0.002(-0.61)$ & $-0.033(-0.93)$ & $-0.002(-0.74)$ \\
Education level of household & $0.022(2.64) * *$ & $0.045(0.33)$ & $0.012(1.42)$ \\
Cooperative membership & $0.043(3.11) * * *$ & $0.029(2.50) * *$ & $0.079(1.94) * *$ \\
Total family size & $0.002(1.73) *$ & $-0.038(-2.71) * *$ & $-0.039(-2.48) * *$ \\
Total farm size & $-0.012(-1.88) * *$ & $-0.029(-2.33) * *$ & $-0.049(-2.46) * *$ \\
Vegetable farming experience & $0.007(2.16) * *$ & $0.004(1.78) *$ & $0.009(2.62) * *$ \\
Access to irrigation & - & - & $0.020(3.26) * * *$ \\
Credit access & $0.012(0.28)$ & $-0.026(-0.44)$ & $0.017(0.49)$ \\
Extension contact & $0.013(2.46) * *$ & $0.021(1.97) * *$ & $0.017(2.23) * *$ \\
Distance from market center & $-0.006(-0.26)$ & $-0.002(-0.39)$ & $-0.009(-0.42)$ \\
Total livestock owned & $0.002(0.94)$ & $0.014(1.20)$ & $0.015(1.33)$ \\
Off $/$ non-farm activity & $0.002(0.87)$ & $-0.014(-0.88)$ & $-0.068(-0.53)$ \\
Land fragmentation & $-0.033(-1.66)$ & $-0.015(-0.41)$ & $-0.015(-0.79)$ \\
Soil fertility status & $0.006(2.12) * *$ & $0.081(4.69) * * *$ & $0.044(2.32) * *$ \\
Log pseudo likelihood $=$ & -45.841 & 23.172 & -53.469 \\
\hline
\end{tabular}

Sources: Model results, 2017. *significant at $10 \%$ level; ** significant at $5 \%$ level; $* * *$ significant at $1 \%$ level of significance

\section{Conclusions and recommendation}

The study was designed to estimate and compare efficiency and to examine factors contributing to the variation in efficiency among the irrigation user and non-user vegetable producers in the Kersa district. The results obtained from the stochastic frontier model showed that the mean technical efficiency for irrigation users was $90 \%$ while for irrigation non-user households is $74 \%$. Similarly, the mean allocative efficiency was $64 \%$ and $54 \%$ for irrigation users and non-user farmers, respectively, and the result further indicated that the mean economic efficiency was $58 \%$ and $40 \%$ for irrigation users and non-users, respectively. The results of the Tobit model revealed that education level, cooperative membership, family size, experience in vegetable farming, access to irrigation, extension contact, livestock holding and soil fertility status are found to be positively, but farm size was negatively and significantly influenced resource use efficiency of vegetable farm households in the study area. Cooperative membership was positively and significantly related to resource use efficiency for both farm groups. Therefore, there should be policy intervention to strengthening or building the capacity of the existing cooperatives by providing institutional support to accommodate more farmers into and facilitating farmers to be the member of the existing cooperatives nearby which they can get access to inputs and markets for their products to get the expected benefit.

On the other hand, the positive and significant coefficient of family size suggests that increase in family size may increase resource use efficiency of irrigation users and the inverse is for irrigation non-users in the study area. This show that large family size easily addresses labour constraints on the farms, and availability of irrigation is intensifying family labour use and encourages farmers to allocate family labour efficiently. Farm size is negatively associated with the resource use efficiency for both farm groups in the study area. This could imply that households with small farm size were more efficient than households with large farm size. Therefore, farm households with large farm size should be applying the appropriate agricultural operations at a time and combine their resources in a better way which lead to improve efficiency.

Access to irrigation is playing a significant role in farmers' efficiency. As a result, for rain-fed vegetable producers by upgrading the rain-fed production should be supplemented by irrigation through providing satisfactory institutional support such as rain-water harvesting and soil-water conservation techniques, expansion of irrigation and improved techniques of irrigation should be strengthened and empowered. Extension contact has a significant and positive effect on resource use efficiency of vegetable producers in the study area. Therefore, efforts should be made to strengthening the existing extension service provided to farmers by upgrading knowledge of extension workers through providing short- and long-term training, and should focus on innovative extension delivery systems that enhance farmer's accessibility to effective extension services.

\section{References}

Afriat, S.N, 1972. Efficiency Estimation of the Production Function. International Economic Review13: 568-598. Aigner, D.J, C.A.K. Lovell, and P. Schmidt, 1977. Formulation and estimation of stochastic frontier production 
function models. Journal of Econometrics 6: 21-37

Alimi, T. (2000). Resource Use Efficiency in Food Crop Production in Oyo State of Nigeria. Journal ofMAgriculture and Environment 1 (1): 1-7.

Andreu, L.M., 2008. Studies on the Economic Efficiency of Kansas Farms. Doctoral Thesis Submitted to Kansas State University.

Arega, D. and M.H. Rashid, 2005. The Efficiency of Traditional and Hybrid Maize Production in Eastern Ethiopia: An Extended Efficiency Decomposition. Journal of African Economics, 15:

Arif, A., K. Hectarejime, M. Toshinobu, I. Akira, M. Ichizen and E. Mohectaremed 2012. Stochastic frontier approach to measure technical efficiency of two irrigation systems in Gilgit district, Baltistan region of Pakistan Journal of Food, Agriculture \& Environment Vol.10 (1

Aynalem, G., 2006. Technical Efficiency in Maize Production: A Case of Smallholder

Farmers in Mechakele District, Ethiopia. An M.Sc. Thesis Presented to School of Graduate Studies of Alemaya University.

Bamlaku Alemu and E-A. Nuppenau, 2011. Technical Efficiency of Farming Systems and its Determinants in East Gojjam, Ethiopia“Competition for Resources use: New Drive for Rural Development” Justus Liebig University, Institute for Agricultural Policy and Market Research, Germany.

Bamlaku Alemu, E-A Nuppenau and H. Boland, 2009. Technical Efficiency of Farming Systems across Agroecological Zones in Ethiopia: An Application of Stochastic Frontier Analysis. Med well Agricultural Journal 4(4):202-207.

Benjamin C. A,, C. U Joseph and T. P. Simon, 2011. Analysis of Economic Efficiency of Nigerian Small Scale Farmers: A Parametric Frontier Approach. Department of Agricultural Economics, University of Agriculture, P. M. B. 2373, Makurdi, Benue State, Nigeria.

Bishaw, Badege., 2009. Deforestation and Land Degradation in the Ethiopian Highlands: A Strategy for Physical Recovery. Ethiopian e-Journal for Research and Innovation Foresight 1(1), Inaugural Issue, 5-18.

Bozoglu, M. and V. Ceyhectaren. 2006. Measuring the technical efficiency and exploring the inefficiency determinants of vegetable farms in Samsun Province, Turkey. Agricultural Systems.

Bravo-Ureta B. E, and E. A. Pinheiro, 1997. Technical, Economic and allocative Efficiency in Peasant Farming: Evidence from the Dominican Republic.” Dev. Econ., 35(1): 48-67.

CSA (Central Statistical Agency), 2018. Crop Production Forecast Sample Survey, Report on Area and Crop Production forecast for Major Grain Crops (For Private Peasant Holding, Meher Season), Addis Ababa, Ethiopia.

CSA (Central Statistical Agency), 2017. Crop Production Forecast Sample Survey, Report on Area and Crop Production forecast for Major Grain Crops (For Private Peasant Holding, Meher Season), Addis Ababa, Ethiopia.

Charnes A., W. Cooper and E. Rhodes, 1978. Measuring the Efficiency of Decision Making Units. European Journal of Operational Research 2, 429-444.

Coelli, T. J, D.S. Prasad Rao and G. E. Battese, 1998. An Introduction to Efficiency and Productivity Analysis, Kluwer Academic Publishers, Norwel, Massachusetts, U.S.A.

Coelli, T. J., 1995. Recent developments in frontier modeling and efficiency measurement. Aust. J. Agric. Econ. $39(3): 219-245$

Dawit Kelemework, 2007. A Comparative Analysis of the Technical Efficiency of Irrigated and Rain-fed Agriculture: A Case of Awash and Rift Valleys of Ethiopia Department of Economics, Haramaya University.

Ebong, V.O., U.S. Okoro and E.O. Effiong, 2009. Determinants of technical efficiency of urban farming in uyo metropolis of akwa ibom state, Nigeria. J. Agric. Soc. Sci., 5: 89-92.

EHZAO (East Hararghe Zone agricultural Office), 2016. Annual Agricultural Report, Harar

EHSS (Ethiopian Horticultural Science Society), 2011. Improving Quality Production of Horticultural Crops for Sustainable Development. Jimma University College of Agriculture \& Veterinary Medicine, Jimma, Ethiopia Third Biennial Conference.

Ellis, F., 1988. Peasant Economics: Farm households and agrarian development. Cambridge University Press, Cambridge, UK.

Farrell, M.J., 1957. The Measurement of Productive Efficiency. Journal of Royal Statistical Society, Series A, 120: 253-290.

Fekadu, Gelaw, 2004. Analysis of Technical Efficiency of Wheat Production: A Study in Machekel Woreda, Ethiopia. M.Sc. Thesis Presented to School of Graduate Studies of Haramaya.

Fekadu Mariame and Dandena Gelmesa, 2006. Review of the status of vegetable crops production and marketing in Ethiopia. Uganda Journal of Agricultural Sciences, 2006, 12(2).

Food and Agricultural Organization (FAO), 2006 "Plant Nutrition for Food Security" a guide for integrated nutrient management, Roy Land and Water Development Division FAO, Rome, Italy. Journal of Royal Statistical Society, 120(3): 253-290. 
Gujarati, D. N., 2004. Basic Econometrics. 4th Ed. Tata McGraw-Hill. New Delhi.

Hensher, M., 2001. Financing Health systems through efficiency gains. CMH working paper series. Paper no. WG3.

Himayatullah. K and S. Imranullah, 2011. Measurement of Technical, Allocative and Economic Efficiency of Tomato Farms in Northern Pakistan.

Hussien Hameda, 2007. Influence of credit constraint on technical efficiency of farm households in South-eastern Ethiopia. Department of Economics, Swedish University of Agricultural Sciences, Sweden Department of Agricultural Economics, and Haramaya University, Ethiopia.

IFAD (International Fund for Agricultural Development), 2009. Country Programme Evaluation, Federal Democratic Republic of Ethiopia, Report No. 2045-ET.

Jema Hajji, 2008. Analyzed Production Efficiency of Smallholders' Vegetable-dominated Mixed Farming System in Eastern Ethiopia. Agricultural Sciences (SLU), Uppsala, Sweden. Journal of African Economies, Volume 16, Number 1, PP. 1-7.

United Nations Development Program UNDP. (2015). Ethiopia: Quarterly Economic Brief. Third Quarter. 